\title{
Kepemilikan Institusional, Kinerja Perusahaan, dan Efek Moderasi dari Kepemilikan Institusional Aktif
}

\author{
Rahmat Setiawan \& Moh Maulidi Syarif \\ Fakultas Ekonomi dan Bisnis, Universitas Airlangga \\ e-mail: rahmatsetiawan@feb.unair.ac.id \\ moh.maulidi.syarif-2016@feb.unair.ac.id
}

\begin{abstract}
This research investigate impact of institutional ownership on firm performance, and moderating effect of active institutional ownership. Using purposive sampling and the period of 2012-2016, we obtained 436 observations of 99 manufacturing firms for dependent variable measured by ROA, and 415 observations of 95 manufacturing firms for dependent variable measured by Tobin's Q. We found that institutional ownership had significant positive effect on firm performance. Active institutional ownership as a moderating variable, strengthens the positive effect of institutional ownership on firm performance.
\end{abstract}

Keywords: institutional ownership, firm performance, active institutional investor

\section{A. PENDAHULUAN}

Pola kepemilikan saham perusahaan di negara maju dan berkembang memiliki kesamaan, kepemilikan saham oleh individu saat ini banyak dikelola oleh investor institusi seperti reksa dana (Cornett et al., 2007). Menurut Pirzada et al. (2015) kepemilikan institusional adalah persentase kepemilikan saham yang dimiliki oleh investor institusi seperti, reksa dana, perusahaan sekuritas, asuransi, dana pensiun, institusi keuangan dan lainnya. Tren ini menimbulkan pertanyaan menarik: apakah kepemilikan institusional berpengaruh positif terhadap kinerja perusahaan (Lin dan $\mathrm{Fu}$, 2017).

Terdapat tiga kemungkinan peran dari investor institusi; active monitoring, passive monitoring, dan bekerja sama dengan manajemen untuk melakukan eksploitasi pada pemegang saham minoritas. Pada skenario pertama, pengawasan oleh investor institusi cenderung akan meningkatkan kinerja perusahaan karena sebagai pemegang saham besar dan andal, investor institusi memiliki insentif dan keahlian untuk meng- awasi manajemen, mereka dapat melakukan hal tersebut dengan biaya yang lebih murah daripada investor individu, dan mampu untuk memberikan pengaruhnya terhadap struktur governance dan tindakan perusahaan. Skenario "passive monitoring" menyatakan bahwa investor institusional hanya bertindak sebagai pengawas pasif dan tidak mengintervensi manajemen, melakukan perdagangan saham untuk mendapatkan keuntungan spekulatif jangka pendek yang didasarkan pada keunggulan informasi yang dimiliki atau untuk memenuhi kebutuhan portofolionya (Elyasiani dan Jia, 2010). Berdasarkan skenario ketiga, investor institusi bekerja sama dengan manajemen untuk melakukan ekspropriasi pada pemegang saham minoritas. Dari ketiga skenario ini, salah satu mungkin mendominasi mengenai peran investor institusional (Elsiyani dan Jia, 2010).

Penelitian terdahulu mengenai dampak kepemilikan institusional dan kinerja perusahaan memiliki hasil yang berbeda. Wei dan Zhang (2005) pada penelitiannya menyatakan bahwa kepemilikan institusional berdampak negatif pada kinerja perusahaan (Tobin's Q). Fernando et al 
(2012 pada penelitian yang dilakukan menyatakan bahwa kepemilikan institusional berpengaruh positif pada harga saham perusahaan. Agrawal dan Knober (1996) menunjukkan dalam penelitiannya bahwa kepemilikan institusional tidak berdampak signifikan pada kinerja perusahaan.

Kepemilikan saham oleh institusi dapat dimiliki oleh perusahaan, reksa dana, perusahaan sekuritas, asuransi, dana pensiun, institusi keuangan, dan yayasan. Tipe kepemilikan institusional yang berbeda mungkin memiliki dampak yang berbeda pada kinerja perusahaan. Penelitian-penelitian sebelumnya mengategorikan investor institusi berdasarkan ada tidaknya hubungan bisnis (aktif dan pasif), asal negara (domestik dan asing), dan besar kecilnya kepemilikan saham (Lin dan Fu, 2017).

Penelitian sebelumnya mengenai dampak perbedaan tipe kepemilikan institusional pada kinerja perusahaan dijelaskan oleh Ferreira dan Matos (2008) yang melakukan penelitian dalam skala internasional pada 27 negara selama periode 2000-2005 dan menyatakan bahwa kepemilikan institusional asing dan independen (aktif) meningkatkan Tobin's $Q$ dan kinerja operasi (ROA dan net profit margin), sedangkan koefisien dari kepemilikan institusi pasif dan domestik tidak signifikan. Elsyani dan Jia (2010) menginvestigasi perusahaan Amerika Serikat selama 1992-2004 dan menjelaskan bahwa stabilitas kepemilikan institusi berpengaruh positif pada kinerja perusahaan. Dalam penelitiannya juga menyatakan bahwa investor institusional aktif dan investor yang memiliki 5\% atau lebih saham memiliki pengaruh positif yang lebih besar terhadap kinerja perusahaan daripada investor institusional pasif dan investor dengan kepemilikan saham kurang dari $5 \%$.

Lin dan Fu (2017) melakukan penelitian pengaruh kepemilikan institusional pada kinerja perusahaan pada perusahaan publik China dari
2004-2014. Hasil ini menunjukkan bahwa kepemilikan oleh investor institusional berdampak positif pada kinerja perusahaan. Hal ini mengindikasikan bahwa investor institusi aktif, asing, dan besar memiliki dampak positif yang lebih besar pada kinerja perusahaan daripada investor institusi pasif, domestik, dan kecil.

Indonesia merupakan salah satu, di mana kepemilikan saham dari perusahaan didominasi oleh kepemilikan institusional. Berdasarkan data Bursa Efek Indonesia (BEI), kepemilikan institusional memiliki kepemilikan 73,14\% dari jumlah saham yang beredar pada Maret 2015. Kepemilikan oleh investor institusional ini dimiliki oleh berbagai jenis investor institusional seperti reksa dana, perusahaan investasi, asuransi, broker, yayasan, dan lainnya. Seperti yang sudah dijelaskan sebelumnya, tipe kepemilikan institusional yang berbeda mungkin memiliki dampak yang berbeda pada kinerja perusahaan. Penelitianpenelitian sebelumnya sebagian besar dilakukan pada negara-negara maju, sedangkan penelitian mengenai investor institusional pada kinerja perusahaan belum banyak dilakukan pada negara berkembang seperti Indonesia. Peran kepemilikan institusional di Indonesia masih belum jelas. Tujuan dari penelitian ini untuk menginvestigasi pengaruh kepemilikan institusional pada kinerja perusahaan dan untuk menguji efek moderasi dari kepemilikan institusional aktif.

\section{B. KAJIAN PUSTAKA DAN PENGUJIAN HIPOTESIS}

\section{Kepemilikan Institusional dengan Kinerja Perusahaan}

Terdapat tiga pandangan mengenai pengaruh kepemilikan institusional pada kinerja perusahaan. Mengacu pada pandangan active monitoring, investor institusional secara aktif mengawasi 
kegiatan operasional perusahaan, meminimalisasi adanya ketidakseimbangan (asimetri) informasi dan mengurangi masalah keagenan, serta meningkatkan kinerja perusahaan dengan dua cara (Lin dan $\mathrm{Fu}, 2017)$. Yang pertama, investor institusi menerapkan kemampuan manajerial yang bagus, professional knowledge, dan hak voting untuk memengaruhi manajemen guna meningkatkan efisiensi perusahaan dan corporate governance sebagai tambahan untuk membantu perusahaan membuat keputusan bisnis. Selain itu, ketika perusahaan akan melakukan ekspansi dan membutuhkan dana, investor institusional dapat memberikan akses dengan menggunakan koneksinya guna membantu perusahaan dalam mencari pendanaan. Yuan et al. (2008) mendukung pandangan ini, menggunakan sampel dari perusahaan publik China periode 2001-2005, kepemilikan ekuitas oleh reksa dana berpengaruh positif pada kinerja perusahaan.

Pandangan passive monitoring menyatakan bahwa investor institusi merupakan short term traders yang tertarik untuk mendapatkan keuntungan jangka pendek berdasarkan keunggulan informasi yang dimiliki untuk memenuhi kebutuhan portofolio (Elysiani dan Jia, 2010) daripada mengawasi untuk meningkatkan corporate governance dan kinerja perusahaan. Berdasarkan pandangan exploitation, institutional investor mungkin akan bekerja sama dengan manajemen untuk mengeksploitasi pemegang saham minoritas dan menurunkan kinerja perusahaan. Wei dan Zhang (2005) mendukung pandangan ini, hasil penelitian mereka menyatakan bahwa kepemilikan institusional berpengaruh negatif terhadap Tobin's $Q$. ketiga pandangan tersebut tidak mutually exclusive melainkan mungkin salah satu memainkan peran dominan dalam menjelaskan hubungan antara kinerja perusahaan dan kepemilikan institusional (Elyasiani dan Jia, 2010).
Investor institusi lebih profesional daripada investor individu. Oleh karena itu, mereka lebih mampu untuk membantu meningkatkan kinerja perusahaan dengan membagikan professional knowledge, kemampuan manajerial, dan memberikan akses pendanaan pada perusahaan. Hipotesis penelitian ini mengenai pengaruh kepemilikan institusional terhadap kinerja perusahaan adalah sebagai berikut.

Hipotesis 1: Terdapat pengaruh positif kepemilikan institusional terhadap kinerja perusahaan.

\section{Efek Moderasi Kepemilikan Institusional Aktif pada Kinerja Perusahaan}

Penelitian terdahulu seperti, Lin dan Fu (2017), secara umum mengategorikan investor institusi berdasarkan ada tidaknya hubungan bisnis, negara asal dan besar kecilnya kepemilikan saham. Hasil penelitian mereka mengindikasikan bahwa tipe kepemilikan institusi yang berbeda memiliki dampak yang berbeda pada kinerja perusahaan.

Kepemilikan saham oleh investor institusi aktif diharapkan berhubungan positif dengan kinerja perusahaan karena mereka cenderung tidak memiliki hubungan bisnis dan konflik kepentingan dengan perusahaan tempat berinvestasi, dan cenderung untuk lebih aktif mengawasi perusahaan dan menekan manajer untuk memaksimalkan nilai perusahaan. Investor institusi aktif (reksa dana) memiliki kewajiban untuk memberikan return yang baik bagi para nasabahnya, karena management fees bergantung pada kinerja investasi dan besarnya dana yang dikelola. Oleh karena itu, kepemilikan institusi aktif harusnya memiliki insentif kuat untuk mengawasi kinerja portfolio perusahaan dan mengambil tindakan untuk menghindari penurunan nilai investasi yang dilakukan. Sebaliknya, kepemilikan institu- 
sional pasif mungkin akan melakukan tindakan guna melindungi hubungan bisnis dengan perusahaan tempat berinvestasi dan bertindak sebagai pasif investor (Cornett et al., 2007; Ferreira dan Matos, 2008).

Hipotesis 2: Kepemilikan institusi aktif memperkuat pengaruh positif kepemilikan institusional pada kinerja perusahaan.

\section{B. METODOLOGI DAN DATA}

\section{Sampel}

Sampel yang digunakan pada penelitian ini adalah perusahaan manufaktur yang terdaftar di Bursa Efek Indonesia (BEI) periode 2012-2016, setiap perusahaan harus menerbitkan laporan keuangan dalam bentuk Rupiah. Sampel akhir dari penelitian ini sebesar 436 observasi dari 99 perusahaan manufaktur untuk variabel kinerja perusahaan yang diukur menggunakan ROA, dan 415 observasi dari 95 perusahaan manufaktur untuk variabel dependen Tobin's Q. Perbedaan observasi pada kedua pengukuran variabel dependen dikarenakan adanya perbedaan data outliers.

\section{Variabel}

\section{a. Variabel Dependen}

Variabel dependen pada yang digunakan adalah kinerja perusahaan. Kinerja perusahaan diproksikan dengan ROA dan Tobin's Q. ROA mewakili kinerja akuntansi dan fokus pada profitabilitas periode tertentu, sedangkan Tobin's Q mewakili kinerja pasar dan mencerminkan harapan masa depan. ROA adalah rasio dari laba bersih dibagi terhadap total aset (Lin dan Fu, 2017). Sedangkan Tobin's Q dihitung sebagai berikut:

$$
\text { Tobin's } Q=\frac{(\text { Equity Market Value }+ \text { Total Hutang })}{\text { Boook Value of Total Asset }}
$$

\section{b. Variabel Independen}

Variabel independen yang digunakan adalah kepemilikan institusional. Kepemilikan institusional merupakan persentase jumlah saham beredar yang dimiliki oleh investor institusional pada akhir tahun (Pirzada, 2015).

\section{c. Variabel Moderasi}

Kepemilikan institusional dapat dibagi berdasarkan ada tidaknya hubungan bisnis, negara asal, dan besar kecilnya kepemilikan saham. Mengacu pada, Cornett et al. (2007), Ferreira dan Matos (2008), serta Lin dan Fu (2017), investor institusi diklasifikasikan apakah mereka aktif atau pasif. Kepemilikan institusional aktif adalah persentase total jumlah saham yang beredar yang dimiliki oleh reksa dana, perusahaan investasi, dan investment advisory firm. Sedangkan kepemilikan institusional pasif, merupakan persentase total jumlah saham beredar yang dimiliki perusahaan asuransi, dana jaminan sosial, broker, bank, dan lainnya. Pada penelitian ini, kita menggunakan variabel dummy untuk mengukur apakah kepemilikan institusional tersebut termasuk aktif atau pasif. Satu, jika perusahaan setidaknya dimiliki oleh reksa dana, perusahaan investasi dan investment advisory firm dengan minimal kepemilikan sebesar 5\% dan nol jika sebaliknya.

\section{d. Variabel Kontrol}

Variabel kontrol pada penelitian ini mengikuti penelitian Lin dan Fu (2017), yaitu ukuran perusahaan (SIZE) dan leverage (LEV). SIZE 
diukur dengan logaritma dari total aset, yang mungkin berpengaruh negatif pada kinerja perusahaan karena perusahaan besar memiliki masalah birokrasi (Xu dan Wang, 1999) dan agency cost yang lebih besar (Sun dan Tong, 2003) serta cenderung lambat dalam merespons perubahan kondisi pasar. Akan tetapi, perusahaan besar mungkin juga akan mendapatkan keuntungan dari skala ekonomi, yang mana dapat meningkatkan kinerja. Sedangkan leverage (LEV) diukur sebagai rasio dari total kewajiban terhadap total aset perusahaan.

\section{Model Penelitian}

Untuk menguji pengaruh kepemilikan institusional pada kinerja perusahaan dan efek moderasi dari kepemilikan institusional pada kinerja perusahaan, penelitian ini menggunakan ordinary least square (OLS). Model penelitiannya adalah sebagai berikut:

a. Model 1

Performance $_{\mathrm{i}, \mathrm{t}}=\alpha+\beta_{1} \mathrm{INST}_{i t}+\beta_{2}$ Size $_{i t}+$ $\beta_{3}$ Leverage $_{i t}+\varepsilon_{i t}$

b. Model 2

$$
\begin{aligned}
\text { Performance }_{\mathrm{i}, \mathrm{t}}= & \alpha+\beta_{1} \text { INST }_{i t}+\beta_{2} \text { DActive }_{i t}+ \\
& \beta_{3} \text { IO }^{*} \text { DActive }_{i t}+\beta_{4} \text { Size }_{i t}+ \\
& \beta_{5} \text { Leverage }_{i t}+\varepsilon_{i, t}
\end{aligned}
$$

Di mana:

Performance $=$ diukur menggunakan ROA dan Tobin's Q

IO $=$ kepemilikan institusional

Dactive $\quad=$ dummy variabel, 1 jika kepemilikan institusional aktif dan nol jika sebaliknya

$\begin{array}{lrl}\text { Size } & \text { ukuran perusahaan mengguna- } \\ & \text { kan logaritma dari total aset } \\ = & \text { rasio total utang terhadap total } \\ \text { Leverage } & \text { aset } \\ = & \text { error }\end{array}$

\section{HASIL PENELITIAN}

\section{Statistik Deskriptif}

Statistik deskriptif variabel-variabel penelitian ini ditunjukkan pada Tabel 1 dan Tabel 2

Tabel 1 Statistik Deskriptif untuk Variabel Dependen ROA

\begin{tabular}{|l|r|r|r|r|l|}
\hline & N & \multicolumn{1}{|c|}{ Min } & \multicolumn{1}{|c|}{ Max } & \multicolumn{1}{c|}{ Mean } & Std. Dev \\
\hline ROA & 436 & $-0,55$ & 0,42 & 0,0506 & 0,09381 \\
INST & 436 & 0,14 & 0,97 & 0,7334 & 0,18628 \\
Active & 436 & 0,00 & 1,00 & 0,0573 & 0,23276 \\
INSTxActive & 436 & 0,00 & 0,97 & 0,0395 & 0,16447 \\
Size & 436 & 0,04 & 14,42 & 11,9220 & 1,82478 \\
Leverage & 436 & 0,20 & 0,82 & 0,4989 & 0,37382 \\
Valid N (listwise) & 436 & & & & \\
\hline
\end{tabular}

Berdasarkan pada tabel 1, selama periode 2012-2016, nilai mean ROA untuk perusahaan manufaktur di Indonesia (0,0593). Nilai maksimum ROA adalah $(0,42)$ dan nilai minimumnya sebesar (-0,55). Sedangkan nilai mean kepemilikan institusional (INST) adalah $(0,7334)$ atau $73,34 \%$ dari jumlah saham yang beredar dengan nilai maksimal $(0,97)$ dan nilai minimal $(0,14)$ hal ini mengindikasikan perusahaan manufaktur di Indonesia didominasi oleh investor institusi.

Tabel 2 Statistik Deskriptif untuk Variabel Dependen Tobin's Q

\begin{tabular}{|l|r|r|r|r|r|}
\hline & N & Min & \multicolumn{1}{|c|}{ Max } & \multicolumn{1}{|c|}{ Mean } & Std. Dev \\
\hline TobinsQ & 416 & 0,14 & 12,70 & 1,5781 & 1,39059 \\
INST & 416 & 0,14 & 0,97 & 0,7237 & 0,18782 \\
Active & 416 & 0,00 & 1,00 & 0,0433 & 0,20371 \\
INSTxActive & 416 & 0,00 & 0,97 & 0,0279 & 0,13519 \\
Size & 416 & 0,04 & 14,42 & 11,8927 & 1,93683 \\
Leverage & 416 & 0,20 & 0,82 & 0,4809 & 0,31054 \\
Valid N (listwise) & 416 & & & & \\
\hline
\end{tabular}

Berdasarkan Tabel 2, selama periode 20122016, nilai mean dari Tobin's Q untuk perusahaan manufaktur Indonesia adalah (2, 0782). Nilai maksimal dan minimal dari Tobin's $Q$ adalah $(12,70)$ dan $(0,14)$. Sedangkan nilai kepemilikan institusional (INST) adalah $(0,7237)$ atau $72,37 \%$, nilai maksimum adalah $(0,98)$ dan nilai minimum adalah $(0,14)$. 
Tabel 3 Korelasi Variabel

\begin{tabular}{|l|l|l|l|l|l|}
\hline & INST & Active & INSTxActive & Size & Leverage \\
\hline INST & 1 & & & & \\
Active & -0.053 & 1 & & & \\
INSTxActive & -0.008 & $0.975^{* *}$ & 1 & & \\
Size & -0.010 & 0.041 & 0.043 & 1 & \\
Leverage & 0.044 & 0.077 & $0.117^{*}$ & 0.025 & 1 \\
\hline
\end{tabular}

Tabel 3 menjelaskan koefisien Pearson correlations antar-variabel independen dan moderasi. Dapat dilihat bahwa INSTxActive memiliki korelasi positif signifikan dengan kepemilikan institusional aktif, leverage memiliki korelasi positif signifikan dengan INSTxActive. Sedangkan korelasi antar-variabel lainnya cenderung rendah.

\section{Hubungan antara Kepemilikan Institusional dan Kinerja Perusahaan}

Berdasarkan Tabel 4 kepemilikan institusional (INST) berpengaruh positif signifikan pada kinerja perusahaan (ROA dan Tobin's Q), yang berarti hipotesis 1 diterima. Hal ini dibuktikan dengan nilai koefisien regresi ROA dan Tobin's Q yang bernilai positif yaitu 0,069 dan 1.241, dengan tingkat signifikansi $0,034<0,05$ dan $0,001<0,05$. Hal ini berarti perusahaan dengan kepemilikan institusional yang tinggi akan meningkatkan kinerja operasi (ROA) dan kinerja pasar perusahaan (Tobin's Q). Perusahaan dengan kinerja akuntansi yang baik akan mendapatkan keuntungan besar yang akan meningkatkan nilai perusahaan. Hal ini merupakan sinyal positif yang ditandai dengan meningkatnya permintaan dan harga saham perusahaan. Investor institusi lebih profesional dari investor individu, investor institusi secara aktif mengawasi bisnis perusahaan, meminimalisasi simetri informasi dan masalah keagenan. Oleh karena itu, investor institusi lebih mampu dalam meningkatkan kinerja perusahaan dengan menerapkan kemam- puan manajerial dan jaringan pendanaan mereka pada perusahaan daripada investor individu (Lin dan $\mathrm{Fu}, 2017)$. Ukuran perusahaan dan leverage sebagai variabel kontrol, berpengaruh signifikan terhadap ROA dan Tobin's Q. Ukuran perusahaan (SIZE) berpengaruh positif terhadap kinerja perusahaan, mengindikasikan bahwa perusahaan besar mungkin akan mendapatkan keuntungan melalui skala ekonomi, yang mana dapat meningkatkan kinerja perusahaan (Lin dan Fu, 2017). Leverage berpengaruh negatif terhadap kinerja perusahaan, hal ini mengindikasikan bahwa semakin besar beban bunga utang akan mengurangi pendapatan perusahaan. Ukuran perusahaan (SIZE) dan leverage tidak berpengaruh signifikan terhadap Tobin's $Q$.

Table 4 Hasil Regresi

\begin{tabular}{|c|c|c|c|c|}
\hline \multirow{2}{*}{ Variabel } & \multicolumn{2}{|c|}{ ROA } & \multicolumn{2}{c|}{ Tobin's Q } \\
\cline { 2 - 5 } & Model 1 & Model 2 & Model 1 & Model 2 \\
\hline INST & $0,069^{*}$ & $0.059^{*}$ & $1.241^{*}$ & $1.093^{*}$ \\
& $(0,034)$ & $(0.007)$ & $(0,001)$ & $(0,003)$ \\
& & & & $-3,212^{*}$ \\
Active & - & $-0.182^{*}$ & - & $(0,034)$ \\
& & $(0.023)$ & & \\
INSTxActive & - & & - & \\
& & & & \\
Size & $0,006^{*}$ & $0.006^{*}$ & 0,052 & 0,053 \\
& $(0,023)$ & $(0.011)$ & $(0,127)$ & $(0,129)$ \\
& & & & \\
Leverage & $-0,110^{*}$ & $-0.115^{*}$ & $-0,316$ & $-0,463^{*}$ \\
& $(0,000)$ & 0.000 & $(0,145)$ & 0,044 \\
\hline Observations & 436 & 436 & 416 & 416 \\
R & 0,463 & 0,473 & 0,194 & 0,220 \\
R Square & 0,214 & 0,224 & 0,037 & 0,048 \\
\hline
\end{tabular}

\section{Efek Moderasi Kepemilikan Institusional Aktif (INSTxActive) pada Kinerja Perusahaan}

Berdasarkan Tabel 3 hasil interaksi dari INSTxActive berpengaruh signifikan pada kinerja perusahaan (ROA dan Tobin's Q), yang berarti hipotesis kedua (H2) diterima. Hal ini dibuktikan, nilai positif koefisien regresi dari ROA dan Tobin's $Q$ yang masing-masing 0,054 dan 0,545 dengan tingkat signifikansi $0,025<0,05$ dan 
$0,006<0,05$. Hasil ini mengonfirmasi bahwa kepemilikan institusional aktif memperkuat pengaruh positif kepemilikan institusional pada kinerja perusahaan. Kepemilikan institusional aktif cenderung tidak memiliki hubungan bisnis dan konflik kepentingan dengan perusahaan dan cenderung untuk lebih aktif mengawasi perusahaan dan menekan manajemen untuk memaksimalkan kesejahteraan pemegang saham (Cornett et al., 2007; Ferreira dan Matos, 2008; Lin dan $\mathrm{Fu}, 2017)$. Reksa dana, perusahaan investasi, investment advisory firm, memiliki kewajiban untuk memberikan return yang bagus bagi para nasabahnya, karena management fees bergantung pada kinerja investasi dan jumlah dana yang dikelola (Yuan et al., 2008).

\section{E. KESIMPULAN}

Investor institusi sebagai investor besar, andal, dan profesional mampu untuk membantu perusahaan untuk meningkatkan kinerja perusahaan dengan menerapkan kemampuan manajerial, dan jaringan pendanaan dengan perusahaan (Lin dan Fu, 2017). Perusahaan dengan kepemilikan institusional yang tinggi memiliki kinerja yang baik, hal ini dibuktikan pada penelitian ini di mana kepemilikan institusional berpengaruh positif terhadap kinerja perusahaan (ROA dan Tobin's Q). Penelitian ini juga menguji efek moderasi dari kepemilikan institusional aktif. Kepemilikan institusional aktif merupakan persentase total jumlah saham beredar yang dimiliki oleh institusi reksa dana, perusahaan investasi, investment advisory firm. Hasil penelitian menyatakan bahwa kepemilikan institusional aktif memperkuat pengaruh positif kepemilikan institusional terhadap kinerja perusahaan.

Hasil penelitian ini mendukung pandangan active monitoring, pengawasan oleh investor institusi cenderung akan meningkatkan kinerja perusahaan, karena sebagai investor besar dan andal, investor institusi memiliki insentif dan keahlian untuk mengawasi manajemen, dan dapat melakukannya dengan biaya yang lebih murah daripada investor individu serta mampu untuk memberikan pengaruh pada struktur governance dan tindakan perusahaan.

Sampel yang digunakan penelitian ini hanya terbatas pada perusahaan manufaktur di Indonesia yang terdaftar pada Bursa Efek Indonesia (BEI). Masih banyak industri lain di Indonesia yang masih bisa digali mengenai dampak kepemilikan institusional terhadap kinerja perusahaan. Hasil penelitian ini juga di harapkan untuk menjadi referensi bagi para pemangku kepentingan dalam membuat keputusan.

\section{F. DAFTAR RUJUKAN}

Agrawal, A. dan Knoeber, C.R. 1996. Firm Performance and Mechanisms to Control Agency Problems between Managers and Shareholders. Journal of Financial and Quantitative Analysis, 31, 377-397.

Brickley, J., Lease, R., dan Smith, C. 1988. Ownership Structure and Voting on Antitakeover Amendments. Journal of Financial Economics, 20, 267-292.

Chen, Z., Du J., Li, D., dan Ouyang, R. 2013. Does Foreign Institusional Ownership Increase Return Volatility? Evidence from China. Journal of Banking and Finance, 37, 660-669.

Core, John E., R.W. dan D. Flacker. 1999. Corporate Governance, CEO Compensation, and Firm Performance. Journal of Financial Economics, 51, 371-406.

Cornett, M.M., Marcus A.J., Saunders, A., dan Tehranian, H. 2007. The Impact of Institu- 
sional Ownership on Corporate Operating Performance. Journal of Banking and Finance, 31, 1771-1794.

David, P., dan Kochhar, R. 1996. Barriers to Effective Corporate Ownership, and the Role of Institusional Investor: Implications for Theory and Practice. European Management Journal, 14, 457-466.

Gillan, S. dan Starks, L. 2003. Corporate Governance, Corporate Ownership, and the Role of Institusional Investor: a Global Perspective. Journal of Applied Finance, 13, 4-22.

Elyasiani, E. dan Jia, J. 2010. Distribution of Institutional Ownership and Corporate Firm Performance. Journal of Banking and Finance, 34, 499-533.

Fernando, C.S., Gatchev, V.A., and Spindt, P.A. 2012. Institutional Ownership, Analyst Following, and Share Prices. Journal of Banking and Finance, 36, 2175-2189.

Ferreira, M. dan Matos, P. 2008. The Colors of Investors Money: the Role of Institutional Investor around the World. Journal of Financial Economics, 88, 499-533.

Li, D., Nguyen, Q.N., Pham, P.K., and Wei, S.X. 2011. Large Foreign Ownership and Firm Level Stock Return Volatility in Emerging Markets. Journal of Financial and Quantitative Analysis, 46, 1127-1155.

Lin, Y.R. dan Fu, X.M. 2017. Does Institutional Ownership Influence Firm Performance? Evidence from China. International Re- view of Economics and Finance, 49, 1757.

Mc Connel, J.J. dan Servaes, H. 1990. Additional Evidence on Equity Ownership and Corporate Value. Journal of Financial Economics, 27, 595-612.

Pirzada, K., Mustapha, M.Z.B., and Wickramasinghe, D. 2015. Firm Performance, Institusional Ownership and Capital Structure: a Case of Malaysia. Procedia-Social and Behavioral Sciences, 211, 170-176.

Shleifer, A. dan Vishny, R.W. 1986. Large Shareholders and Corporate Control. Journal of Political Economy, 94, 461-488.

Shleifer, A. and Vishny, R. 1997. A Survey of Corporate Governance. Journal of $\mathrm{Fi}$ nance, 52, 737-775.

Stiglitz, J. 2000. Capital Market Liberalization, Economic Growth, and Stability. World Development, 28, 1075-1086.

Wei, Z., Xie, F., dan Zhang, S. 2005. Ownership Structure and Firm Value in China's Privatized Firms: 1991-2001. Journal of Financial and Quantitative Analysis, 40, 87-108.

Xu, X. dan Wang, Y. 1999. Ownership Structure and Corporate Governance in Chinese Stock Companies. China Economic Review, 10(1), 75-98.

Yuan, R., Xiao, J.Z., \& Zou, H. 2008. Mutual Funds' Ownership and Firm Performance: Evidence from China. Journal of Banking \& Finance, 32(8), 1552-1565. 